\title{
Identification and Functional Characterization of Novel Mutations in the Melanocortin-4 Receptor
}

\author{
Sigri Beckers ${ }^{a} \quad$ Doreen Zegers $^{a} \quad$ Fenna de Freitas $^{a} \quad$ Armand V. Peeters $^{a} \quad$ Stijn L. Verhulst ${ }^{b}$ \\ Guy Massa $^{c} \quad$ Luc F. Van Gaal $^{d} \quad$ Jean-Pierre Timmermans ${ }^{e} \quad K^{2}$ ristine N. Desager ${ }^{b}$ Wim Van Hul $^{a}$ \\ ${ }^{a}$ Department of Medical Genetics, University of Antwerp and Antwerp University Hospital, \\ ${ }^{\mathrm{b}}$ Department of Paediatrics, Antwerp University Hospital, \\ ${ }^{c}$ Department of Paediatrics, Virga Jesse Hospital, Hasselt, \\ ${ }^{\mathrm{d}}$ Department of Endocrinology, Diabetology and Metabolism, Antwerp University Hospital, \\ ${ }^{\mathrm{e}}$ Laboratory of Cell Biology and Histology, University of Antwerp, Belgium
}

\section{Keywords}

Obesity · Melanocortin-4 receptor - Mutation analysis

\section{Summary}

Objective: Melanocortin-4 receptor (MC4R) deficiency is the most common cause of monogenic obesity. In the present study, we screened the $M C 4 R$ gene for mutations in a population of overweight and obese children and adolescents. Method: Cross-sectional mutation analysis of 112 overweight/obese children and adolescents and 121 lean individuals. Results: We identified 11 sequence variations, 5 of which were present in our control population or had been previously reported as polymorphisms. The remaining 6 variations are disease-causing mutations including 2 novel ones: a I186V mutation and a F280L mutation. The 4 previously described mutations (D90N, M200V, P2600, Q307X) were identified in single probands. Using confocal imaging, we demonstrated that F280L and $P 2600$ cause intracellular retention of the mutant receptor. No difference in cell surface expression could be detected for the I186V mutation. Using a cAMP responsive luciferase vector, we demonstrated that the receptor with $1186 \mathrm{~V}$ is unable to activate its intracellular signaling pathway while the P2600 mutation causes reduced activation of the receptor. Conclusion: We detected MC4R deficiency in 6 patients from our cohort, amounting to a prevalence of $5.3 \%$. Two novel mutations were identified. We also confirmed that intracellular retention is a common pathogenic effect of $M C 4 R$ mutations.

\section{Introduction}

Obesity is one of the most important health problems in today's world. It is caused mainly by an interaction between environmental and genetic factors. However, several studies have shown that obesity can also be caused by a mutation in a single gene. These monogenic forms of obesity have been found to be caused by mutations in the genes encoding leptin [1], leptin receptor [2], prohormone convertase 1 [3], proopiomelanocortin [4], melanocortin-3 receptor [5, 6], melanocortin-4 receptor (MC4R) [7, 8] and single minded 1 [9]. MC4R deficiency has proven to be the most common cause of monogenic obesity, with a frequency of about $2.5 \%$ in the obese population [10].

The MC4R is a 7 transmembrane receptor expressed in the hypothalamus [11, 12]. This receptor is activated by $\alpha$-melanocyte stimulating hormone ( $\alpha$-MSH), its endogenous agonist, and is antagonized by agouti-related peptide (AgRP) [11-13]. Leptin stimulates the production of proopiomelanocortin, the precursor of $\alpha-\mathrm{MSH}$ and inhibits the expression of $\mathrm{AgRP}$, thus generating an anorexigenic signal. The crucial role of the MC4R in food intake regulation was demonstrated through generation of a knock-out mouse. Huszar et al. [14] showed that MC4R knock-out mice display a maturity-onset obesity phenotype with hyperphagia, increased linear growth, hyperinsulinemia and hyperglycemia. In 1998, two groups simultaneously reported the first human mutations in MC4R: they found a deletion and insertion which completely abolished receptor function. Probands carrying these mutations had severe early-onset obesity and hyperphagia without other complications [7, 8]. Since then, MC4R has been widely stud-

\section{KARGER}

Fax +497614520714

Information@Karger.de

www.karger.com (c) 2010 S. Karger GmbH, Freiburg

Accessible online at:

www.karger.com/ofa
Prof. Dr. Wim Van Hul

Department of Medical Genetics

University of Antwerp and Antwerp University Hospital

Universiteitsplein 1, 2610 Antwerp, Belgium

Tel. + 323 27597-61, Fax -23

wim.vanhul@ua.ac.be 
ied in several populations of obese adults and children. Mutation frequencies vary considerably between populations, ranging from 0.5 to $6 \%$ [15-24].

Most mutations were found in the heterozygous state, although some homozygous mutations have also been reported [19, 25-28]. Several MC4R mutations have been functionally characterized. They were mostly found to impair proper receptor trafficking to the plasma membrane, and the mutant receptors were therefore found to be retained intracellularly [29-31]. Mutations can also impair receptor function through affecting ligand binding, constitutive activity and agonist-stimulated signaling [32, 33].

Recently, $M C 4 R$ has also been implicated in the etiology of complex obesity. A genome-wide association study identified variants downstream from $M C 4 R$ to be significantly associated with common obesity in Caucasian populations [34]. This finding was subsequently replicated by several other investigators [35-38] and is now accepted as a genuine association signal for complex obesity. These findings demonstrate that MC4R is important in the development of both monogenic obesity and common obesity.

Previously, we reported that no mutations were present in a population of Belgian obese adults, adolescents and children [39]. In the current study, we present data from a mutation analysis in a second group of overweight and obese children and adolescents.

\section{Material and Methods}

\section{Subjects}

112 unrelated overweight and obese children and adolescents (51 boys and 61 girls; adolescence defined as age $\geq 12$ years; table 1 ) consulting the Child Obesity Clinics from the Antwerp University Hospital and the Virga Jesse Hospital, Hasselt, both in Belgium, were recruited. The patient population has a mixed ethnicity. The percentile lines that pass through the BMI of 25 and 30 at 18 years of age on the Flemish age- and sex-specific BMI growth curves are used as cut-off for the diagnosis of overweight and obesity in our cohort [40]. For patients carrying $M C 4 R$ mutations, parents and other family members, if available, were contacted for inclusion in the study. A control population of 121 lean subjects was also examined for mutations in $M C 4 R$ (inclusion criterium: BMI between 18.5 and $25 \mathrm{~kg} / \mathrm{m}^{2}$ ). All control subjects were recruited among personnel from Antwerp University Hospital and the Department of Medical Genetics. All control subject were of Caucasian origin (table 1). All participants gave their written informed consent. The study protocol was approved by the local ethics committee.

\section{Anthropometry}

Height was measured to the nearest $0.1 \mathrm{~cm}$. Weight was measured on a digital scale to the nearest $0.1 \mathrm{~kg}$. BMI was calculated for all patients, and $\mathrm{Z}$-scores were based on the Flemish growth curves [40].

\section{Mutation Analysis of MC4R}

The $M C 4 R$ gene was amplified by PCR on genomic DNA isolated from whole blood. The entire coding region of $M C 4 R$ (999 bp) was screened for mutations using denaturing high performance liquid chromatography (DHPLC) or high-resolution melting curve analysis (HRM). The control population was screened with both methods. DHPLC analysis was carried
Table 1. Characteristics of the study populations ${ }^{\mathrm{a}}$

\begin{tabular}{lccc}
\hline & Children & Adolescents & Control subjects \\
\hline $\mathrm{N}$ & 71 & 41 & 121 \\
Age, years & $8.7 \pm 0.3$ & $14.0 \pm 0.2$ & $38.1 \pm 0.9$ \\
Male/female & $34 / 37$ & $17 / 24$ & $14 / 107$ \\
Weight, kg & $50.3 \pm 2.0$ & $94.3 \pm 2.7$ & $63.9 \pm 0.7$ \\
Height, m & $1.37 \pm 0.02$ & $1.67 \pm 0.01$ & $1.68 \pm 0.01$ \\
BMI, kg/m & $26.1 \pm 0.5$ & $33.8 \pm 0.7$ & $22.6 \pm 0.1$ \\
BMI Z-score & $2.5 \pm 0.1$ & $2.5 \pm 0.1$ & - \\
\hline
\end{tabular}

${ }^{a}$ Mean value \pm standard error of mean is given.

${ }^{\mathrm{b}} \mathrm{BMI} \mathrm{Z}$-score was based on data from the Flemish Growth Charts [40].

out as described previously [39]. Briefly, $M C 4 R$ was divided into 3 amplicons which were all analyzed on a WAVE Nucleic Acid Fragment Analysis System (Transgenomic Inc, Crewe, UK). Samples with aberrant chromatograms compared to wild type were sequenced to confirm and identify nucleotide changes. For HRM, the coding region of $M C 4 R$ was divided into 4 amplicons. HRM was performed using the Lightcycler LC480 Real-Time PCR System (Roche, Penzberg, Germany) with incorporation of LCGreen+ fluorescent dye (Idaho Technology Inc., Salt Lake City, UT, USA) into the PCR product. Samples with melting curves deviating from wild type were sequenced. Sequencing was performed with ABI BigDye Terminator v1.1 Cycle Sequencing kits on an ABI Prism Genetic Analyzer 3130xl (Applied Biosystems Inc, Foster City, CA, USA). Primer sequences for DHPLC, HRM and sequencing are available upon request.

\section{Subcellular Localization of Mutant Receptor}

Wild-type $M C 4 R$ was amplified directly from genomic DNA of a control individual using primers which add a NheI (5'-ATC GAT GCT AGC TCC TGC CAG CAT GGT GAA CTC C-3’) and a HindIII (5'-GTA ACT AAG CTT ATA TCT GCT AGA CAA GTC-3’) restriction site upstream and downstream of $M C 4 R$ respectively. PCR was performed using iProof High-Fidelity DNA polymerase (Bio-Rad, Hercules, CA, USA), according to the manufacturer's protocol. Using NheI and HindIII, wild-type $M C 4 R$ was cloned into the mammalian expression vector pEGFP-N1 (Clontech, Mountain View, CA, USA) which adds a C-terminal EGFP tag to MC4R. Mutant receptors carrying I186V, P260Q or F280L were created with in vitro mutagenesis using a Quikchange Site Directed Mutagenesis kit (Stratagene, La Jolla, CA, USA). All cloned products were sequenced using a standard sequencing protocol as described above.

COS-7 cells were maintained in DMEM supplemented with $10 \%$ fetal calf serum (FCS), 100 units/ml penicillin and $100 \mu \mathrm{g} / \mathrm{ml}$ streptomycin (Invitrogen, Carlsbad, CA, USA). Cells were incubated at $37^{\circ} \mathrm{C}$ in humidified air containing $5 \% \mathrm{CO}_{2}$. One day prior to transfection, $1 \times 10^{4}$ COS-7 cells were grown on collagen-coated $(0.48 \mathrm{mg} / \mathrm{ml}$ collagen; BD Biosciences, Franklin Lakes, NJ, USA) coverslips (Knittel Gläser, Braunschweig, Germany) in 24-well plates. Transfection was done using Fugene 6 transfection reagent according to manufacturer's protocol (Roche): $200 \mathrm{ng}$ of wild-type or mutant MC4R expression vector was transfected at a 3:1 ratio to Fugene 6 transfection reagent. $24 \mathrm{~h}$ after transfection, plasma membranes were fluorescently stained with $1 \mu \mathrm{g} / \mathrm{ml}$ tetramethyl-rhodamine wheat germ agglutinin conjugate (Invitrogen). After staining, cells were fixed with $4 \%$ formaldehyde and mounted on microscope slides. Vectashield Mounting medium (Vector Laboratories, Burlingame, CA, USA) was used to preserve fluorescence. Cells were visualized using a Zeiss LSM 510 confocal microscope equipped with argon (excitation, $488 \mathrm{~nm}$ ) and helium-neon (excitation, 543 and $633 \mathrm{~nm}$ ) lasers. 
Table 2. Clinical phenotype of probands carrying $M C 4 R$ mutations

\begin{tabular}{lccllll}
\hline Mutation & Age, years & Sex & Height, $\mathrm{m}$ & Weight. $\mathrm{kg}$ & BMI, kg/m & BMI Z-score $^{\mathrm{a}}$ \\
\hline D90N & 3.7 & boy & 1.035 & 29.0 & 27.1 & 4.33 \\
I186V & 7.3 & girl & 1.353 & 53.0 & 29.0 & 3.18 \\
M200V & 10.4 & boy & 1.398 & 50.0 & 25.6 & 2.13 \\
P260Q & 10.9 & girl & 1.540 & 78.4 & 33.1 & 2.61 \\
F280L & 12.2 & girl & 1.630 & 96.3 & 36.3 & 2.87 \\
Q307X & 14.8 & girl & 1.775 & 112.4 & 35.8 & 2.82 \\
\hline
\end{tabular}

${ }^{\mathrm{a}} \mathrm{BMI}$ Z-score was based on data from the Flemish Growth Charts [40].
Intracellular Signaling of Mutant Receptor

Wild-type $M C 4 R$ cloned in the mammalian expression vector pcDNA3 was kindly provided by Dr. G. Yeo (Cambridge, UK). Mutant MC4Rs were created with a Quikchange Site Directed Mutagenesis kit (Stratagene, La Jolla, CA, USA) according to the manufacturer's protocol. All cloned products were sequenced using a standard sequencing protocol as described above. HEK293T cells were maintained in DMEM supplemented with $10 \%$ FCS, 100 units $/ \mathrm{ml}$ penicillin and $100 \mu \mathrm{g} / \mathrm{ml}$ streptomycin (Invitrogen). Cells were incubated at $37{ }^{\circ} \mathrm{C}$ in humidified air containing $5 \% \mathrm{CO}_{2}$. Intracellular signaling capacity of mutant receptors was determined using a cAMP responsive luciferase construct (pCRE-Luc; Stratagene). One day before transfection, $1.5 \times 10^{4}$ cells were seeded on a 96-well plate. Cells were transfected with $25 \mathrm{ng}$ wild-type or mutant MC4R expression vector, $25 \mathrm{ng}$ pCRE-Luc and $2.5 \mathrm{ng}$ internal control plasmid pRL-TK, which constitutively expresses Renilla luciferase. Transfections were carried out using Fugene 6 transfection reagent according to the manufacturer's protocol (Roche). $24 \mathrm{~h}$ after transfection, cells were stimulated with varying concentrations of $\alpha$-MSH $\left(10^{-5}\right.$ to $10^{-10}$ mol/l; Bachem, Well-am-Rein, Germany) diluted in culture medium. Cells were allowed to incubate for $3 \mathrm{~h}$ in the presence of $\alpha-\mathrm{MSH}$. Then the cells were lysed and Firefly and Renilla luciferases were sequentially activated and quenched using the Dual-Glo Luciferase assay System (Promega, Madison, WI, USA). Luminescence was detected with a Victor $^{2}$ Multilabel Plate Reader (Perkin Elmer, Waltham, MA, USA). For all experimental constructs, the assay was repeated four times. The ratio of firefly-to-renilla luciferase luminescence was calculated to correct data for transfection efficiency. Data for experimental constructs were all normalized to the firefly-to-renilla ratio for wild-type $M C 4 R$ stimulated with $10^{-5} \mathrm{~mol} / \mathrm{l} \alpha-\mathrm{MSH}$ (set at $100 \%$ ).

\section{Results}

Screening of $M C 4 R$ in our patient and control population revealed 11 sequence variations. Three of these were found in both our patient and control population (V103I, I198I and I251L). G324G was only identified in a control individual while T112M was only found in an obese individual, but this variant has previously been reported as a polymorphism [22, 41]. V103I and I251L were also previously described as polymorphisms; their minor alleles lead to a slightly reduced body weight $[42,43]$.

The mutations D90N, I186V, M200V, P260Q, F280L and Q307X were each found heterozygously in single, obese probands, but not in our control population. D90N and M200V have been described previously [17, 44]. During the

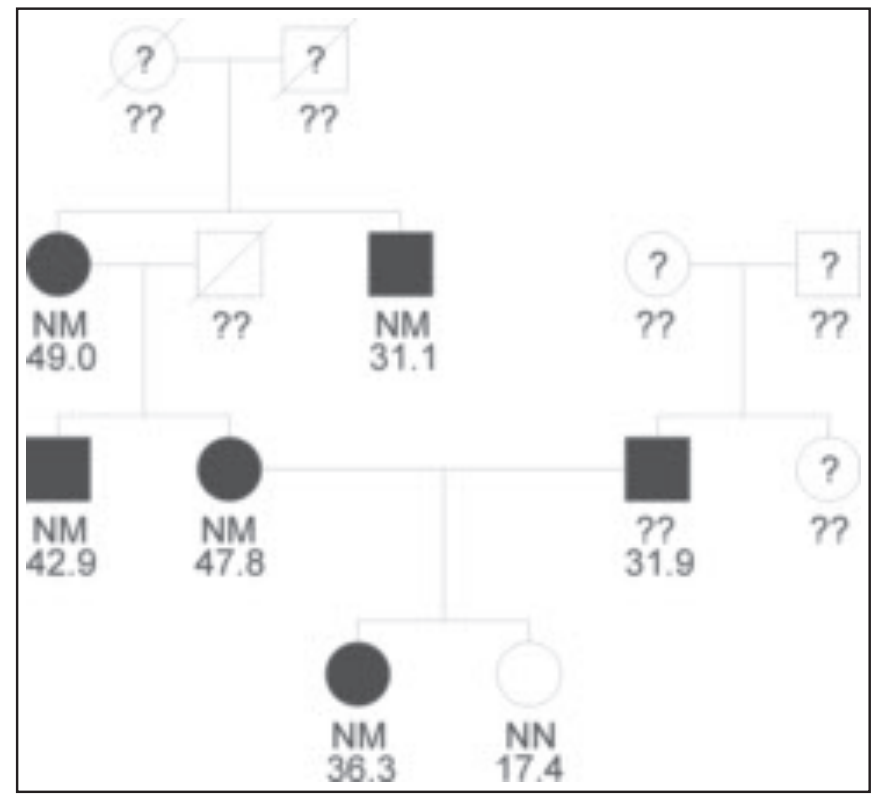

Fig. 1. Pedigree of family with $M C 4 R$ F280L mutation.

Filled symbols are individuals with obesity. The first line below the symbols indicates the genotype status for F280L: N, normal allele; M, mutant allele; ??, unknown genotype. The second line shows BMI of the individual at investigation.

course of this study, P260Q and Q307X were also described $[45,46]$. Characteristics of the probands are given in table 2.

For all mutation carriers, we tried to contact parents and other family members to determine whether the mutation cosegregates with obesity. We could only include family members for the probands carrying D90N and F280L.

The mother of the proband with D90N was also obese $\left(\mathrm{BMI}=43.5 \mathrm{~kg} / \mathrm{m}^{2}\right)$ and was found to carry the same mutation. No other family members were available, but familial anamnesis reports overweight in both the mother's and the father's family. The father, who was not willing to participate in the study, was also reported to be morbidly obese (BMI = $43.6 \mathrm{~kg} / \mathrm{m}^{2}$ ).

When studying the family of the proband with F280L, we clearly demonstrated that this mutation co-segregates with obesity (fig. 1). We further found that the mutation was inher- 
Fig. 2. Localization of wild-type and mutant MC4R.

Images were made with a Zeiss LSM 510 confocal microscope equipped with argon (excitation, $488 \mathrm{~nm}$ ) and helium-neon (excitation, 543 and $633 \mathrm{~nm}$ ) lasers. The first panel shows EGFP fluorescence (excitation $488 \mathrm{~nm}$ ). The second panel visualizes fluorescence of the tetramethyl-rhodamine wheat-germ agglutinin conjugate (TMR-WGA) which binds to the plasma membrane (PM) (excitation $543 \mathrm{~nm}$ ). A merged view is shown in the third panel. A Empty pEGFP-N1 expression vector: EGFP is expressed ubiquitously throughout the cell, without co-localization with the PM B MC4R wild type: co-localization of EGFP and TMRWGA fluorescence indicates the localization of the wild-type MC4R on the PM. C MC4R I186V: co-localization of green and red fluorescence indicates that this mutant receptor is present on the PM. D MC4R P260Q: no co-localization of EGFP and TMR-WGA is present on the merged view, indicating that this mutant MC4R is not expressed on the PM.

E MC4R F280L: the mutation causes intracellular retention of the receptor since no colocalization of EGFP and TMR-WGA is seen.
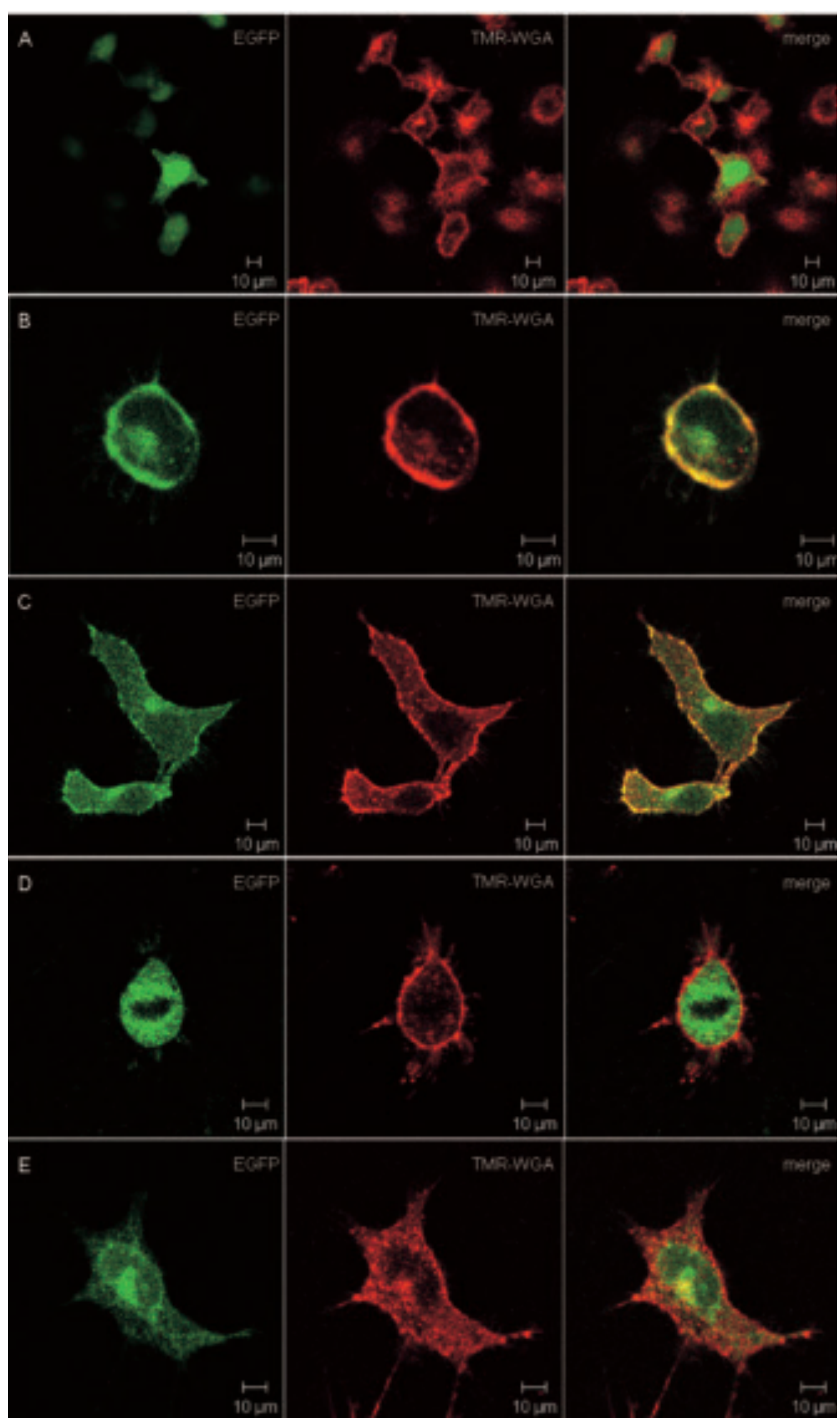

ited from the mother. Furthermore, the maternal grandmother, uncle and great-uncle also harbored this mutation. All mutation carriers were severely obese. The lean younger sister of the proband was found to carry wild-type $M C 4 R$. The obese father $\left(\right.$ BMI $\left.=31.9 \mathrm{~kg} / \mathrm{m}^{2}\right)$ was not included in the family analysis.
Functional characterization was performed for the two newly identified mutations (I186V and F280L) and for P260Q since the experiments performed here had not been previously described for this mutation. The other mutations were not included in the functional analysis since they had been previously characterized [44, 45, 47, 48]. 


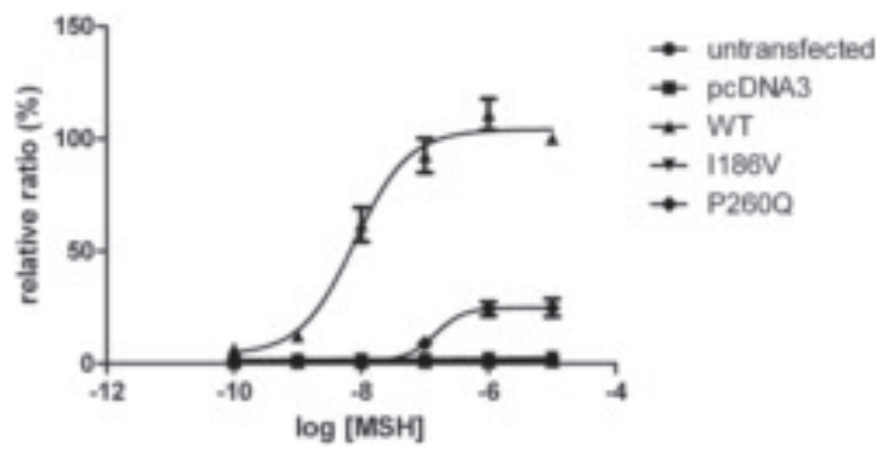

Fig. 3. Intracellular signaling of wild-type and mutant MC4R. HEK293 cells were transfected with pcDNA3 with wild-type MC4R, MC4R with I186V or P260Q, in combination with a pCRE-Luc reporter and pRL-TK as an internal control. After stimulation with different concentrations of $\alpha-\mathrm{MSH}$, luciferase luminescence was measured. Relative ratios are shown (compared to wild type). Error bars represent standard deviation.

The 3 mutant constructs were created in a mammalian pEGFP-N1 expression vector to study cellular localization of these mutants. Images of transfected cells were made with a confocal microscope. Wild-type MC4R is located on the plasma membrane (fig. 2B). Confocal imaging of P260Q and F280L showed that both mutations are retained intracellularly (fig. 2D-E). For I186V, we demonstrate here that the mutation does not alter membrane expression of the protein. Colocalization of EGFP and tetramethyl-rhodamine wheat-germ agglutinin conjugate (TMR-WGA) is clearly present (fig. 2C).

For the $186 \mathrm{~V}$ mutation, we also performed a luciferase assay to determine the ability of the mutant receptor to stimulate cAMP production in response to $\alpha-\mathrm{MSH}$. We also included the $\mathrm{P} 260 \mathrm{Q}$ mutation in this assay to compare our results with those obtained by Stutzmann et al. [45] during the course of our study. For this experiment, both mutant constructs were created in a mammalian pcDNA3 expression vector. Measurement of luciferase as an indirect measure of intracellular cAMP showed complete loss of function for the I186V mutation (fig. 3). At maximal stimulation, this mutant receptor only showed $1.7 \%$ of activation compared to the wild-type receptor. P260Q caused a severe reduction in intracellular signaling capacity, as demonstrated by a maximal activation of $7.9 \%$ compared to wild type (fig. 3).

\section{Discussion}

MC4R deficiency is widely accepted as the most common cause of monogenic obesity. In children presenting with severe early-onset obesity, screening of $M C 4 R$ is therefore a first step in determining a possible genetic cause of the disease. We screened the coding region of $M C 4 R$ in a population of 112 severely overweight and obese children and adolescents and identified 6 mutation carriers, amounting to an
$M C 4 R$ mutation frequency of $5.3 \%$. This is in contrast to our previous study in which we did not identify any MC4R mutations in a cohort of 123 overweight and obese children and adolescents [39].

However, there are significant differences between the two study populations. In our first study, the study cohort had consisted almost entirely of adolescents (3 children vs. 120 adolescents) while we now studied a population of 71 children (age $<12$ years) and 41 adolescents (age $\geq 12$ years). Furthermore, the mean age of the adolescent sample was also higher in our initial study (mean age $=16.8$ years) than in the current cohort (mean age $=14.1$ years). The entire cohort now also includes much younger children than those from the previous report (age range $=0.4-19$ years vs. 8-20 years). Therefore, we conclude that our population now consists of children with early-onset obesity while our previous report probably contained a large number of patients with pubertal onset of obesity. Furthermore, our first study only included children of Caucasian descent while the second cohort also contains individuals of other ancestries. Finally, the first group of children and adolescents was recruited through an adult outpatient obesity clinic while the second group has been recruited through specific pediatric obesity centers in Antwerp and Hasselt. These differences may explain why we now find $M C 4 R$ mutations at a high frequency in our population while we did not detect any mutation previously. The current frequency is in line with other studies dealing with children with severe early-onset obesity $[18,19,30]$.

In total, 11 sequence variations were found in our study. Four of these variations (V103I, T112M, I198I and I251L) are previously reported polymorphisms while another one ( $\mathrm{G} 324 \mathrm{G})$ is unreported, but since it is a synonymous mutation which we found in a control subject, we are convinced that this polymorphism is not related to obesity.

On the other hand, several arguments favor the hypothesis that the remaining 6 variations are disease-causing. None of these is found in a control cohort, and they cause either an amino acid substitution or an early stop codon. Furthermore, 4 variations have been previously reported in obese patients, and the disease-causing aspect of some has been confirmed in functional studies.

The D90N mutation was first reported in a single proband by Biebermann and colleagues in 2003 [44]. This mutation was found in a patient with early-onset obesity, but no conclusions on segregation with obesity could be drawn since the mother did not carry the mutation and the father was not available for inclusion. Functional characterization demonstrated that this mutation did not alter cell surface expression or ligand binding. However, no intracellular cAMP accumulation was observed after stimulation with NDP- $\alpha-\mathrm{MSH}$. Cotransfection studies and a sandwich ELISA showed that the D90N mutation exerts its pathogenic effect through a dominant negative influence on the wild-type receptor. This was the first mutation in which a dominant negative effect could 
be demonstrated [44]. In the current study, we also detected this mutation in a single proband with early-onset obesity. We were also able to include the obese mother in our analysis and demonstrated that she carried this mutation too. Based on the clinical data, co-segregation with obesity and the functional effects demonstrated by others, we conclude that the D90N mutation is the cause of the early-onset obesity seen in our patient.

Branson and colleagues [17] first described two patients with a M200V mutation in the fifth transmembrane (TM) domain of MC4R. These patients were obese and had characteristics of binge eating. Functional description of this mutation showed that no difference from wild type could be demonstrated for cell surface expression, ligand binding or intracellular signaling capacity [47]. We also identified an obese patient carrying this mutation. His father is of normal weight $\left(\mathrm{BMI}=23.9 \mathrm{~kg} / \mathrm{m}^{2}\right)$, but his mother has a history of obesity. She has a BMI of $38.5 \mathrm{~kg} / \mathrm{m}^{2}$ after gastric banding. Since none of the parents were available for genetic screening, no conclusion on segregation with obesity can be drawn. Therefore, we cannot make any definite conclusions on the pathogenic character of this mutation at the moment. However, the fact that this mutation has not been identified in control subjects by us or others [17] leads us to speculate that it may have a negative effect on MC4R that is not identifiable through the functional assays currently performed. Further functional testing of this mutation is therefore necessary to further elucidate its effect on MC4R functioning.

The nonsense mutation at codon 307 (Q307X) was initially identified in an 8-year-old obese boy [46]. No functional characterization of this mutant was performed at that time. Here, we identified this nonsense mutation in a 14-year-old girl with severe obesity. No family data are available. We did not perform functional assays for this mutation since it has been previously described that truncation of the $M C 4 R$ from codon 306 onwards results in a loss of cell surface expression of the truncated receptor [48]. Furthermore, the di-isoleucine sequence at codons 316/317 was shown to be crucial for cell surface expression of the receptor [49]. Based on these previous data, we conclude that the Q307X nonsense mutation found in our patient and the previously reported case [46] results in a truncated receptor which has lost the ability to be transported to the cell surface.

The P260Q mutation was identified in a 10-year-old patient with severe early-onset obesity. No family data are available for this proband. During the course of our functional experiments, Stutzmann et al. [45] also reported this mutation in two individuals. They reported that this mutation causes a reduced intracellular cAMP accumulation. This result was confirmed in the current study. Here, we also show that this mutation is not expressed on the cell surface by confocal imaging of EGFP-MC4R fusion protein. The mutation causes intracellular retention of the receptor, which is consistent with a reduced intracellular signaling capacity as reported by Stutz- mann et al. [45]. Furthermore, a recent report describes a F261S mutation in a Chinese proband that causes intracellular retention of the mutant receptor [50]. These data also suggest that this region in the 6th TM domain of MC4R may be an important region for the cellular localization of the receptor.

We were able to identify 2 previously unreported mutations, F280L and $1186 \mathrm{~V}$. We found the F280L mutation in a severely obese girl of 12 years. This mutation co-segregated in the family from the mother's side. The proband's lean younger sister was wild type for $M C 4 R$. The obese father was not willing to participate, but we showed that the diseasecausing mutation is inherited from the mother. We developed an EGFP-MC4R fusion protein, which allowed us to conclude that the mutant receptor is localized inside the cell instead of on the plasma membrane. Therefore, we hypothesize that the intracellular retention of the mutant receptor causes a reduced inhibition of food intake in this family, ultimately leading to the observed obesity.

A 7-year-old obese girl was found to carry the I186V mutation in the 4th TM domain of MC4R. Her mother is of normal weight $\left(\mathrm{BMI}=23.7 \mathrm{~kg} / \mathrm{m}^{2}\right)$ while her father is also obese $(\mathrm{BMI}=$ $31.8 \mathrm{~kg} / \mathrm{m}^{2}$ ). Parents, however, were not available for genetic screening. Confocal imaging showed that this mutation is expressed on the cell surface similar to wild type. By indirect cAMP measurements, we were able to demonstrate that this mutation causes a complete loss of function of the receptor. However, we cannot conclude whether this is caused by a defect in ligand binding or intracellular signaling as we did not perform binding assays. A G181D mutation in TM4 has been previously reported and was also found to cause a complete loss of function as determined by measurement of intracellular second messenger production and ligand-binding assay $[10,51]$. These data strongly suggest that the I186V mutation is pathogenic and is the cause of the obesity seen in the proband.

In conclusion, we identified 6 mutations in patients with early-onset obesity, indicating a mutation frequency of $5.3 \%$ in this population of Belgian obese children. Two (I186V and F280L) of the mutations were novel. Functional analysis on these and on a third mutation (P260Q) indicated that 2 of the 3 mutations cause intracellular retention of mutant MC4R. This has been shown to be the most common mechanism through which mutations impair MC4R signaling [29-31]. It has been shown that $81.3 \%$ of childhood obesity-associated mutations in MC4R cause intracellular retention of the receptor. This may correlate with an early onset of the obesity seen in the probands carrying these mutations [29]. Furthermore, Tao and Segaloff [52] proposed a classification scheme for $M C 4 R$ mutations which identifies mutations that impair cell surface expression as an important class of pathogenic mutations (class II mutations). For the I186V mutation, a complete loss of intracellular signaling activity could be demonstrated here. This study again stresses the relevance of performing mutation analysis of $M C 4 R$ in obese children. 


\section{Acknowledgements}

The authors wish to thank Jan Van Daele for technical assistance with confocal imaging. We thank Dr. Jenneke van den Ende and Veerle De Craemer for taking blood samples.

S.B. is a post-doctoral researcher for the Fund for Scientific Research Flanders (FWO-Vlaanderen). D.Z. holds a pre-doctoral specialization scholarship from the Institute for the Promotion of Innovation through
Science and Technology in Flanders (IWT-Vlaanderen). This work was supported by a grant (G0028.05) from the Fund for Scientific Research Flanders (FWO-Vlaanderen) to LVG and WVH.

\section{Disclosure}

The authors declare no conflict of interest.

\section{References}

$\checkmark 1$ Montague CT, Farooqi IS, Whitehead JP, Soos MA, Rau H, Wareham NJ, Sewter CP, Digby JE, Mohammed SN, Hurst JA, Cheetham $\mathrm{CH}$, Earley AR, Barnett AH, Prins JB, O'Rahilly S: Congenital leptin deficiency is associated with severe early-onset obesity in humans. Nature 1997; 387(6636):903-908.

2 Clement K, Vaisse C, Lahlou N, Cabrol S, Pelloux V, Cassuto D, Gourmelen M, Dina C, Chambaz J, Lacorte JM, Basdevant A, Bougneres P, Lebouc Y, Froguel P, Guy-Grand B: A mutation in the human leptin receptor gene causes obesity and pituitary dysfunction. Nature 1998;392(6674):398-401.

3 Jackson RS, Creemers JW, Ohagi S, Raffin-Sanson ML, Sanders L, Montague CT, Hutton JC, O'Rahilly S: Obesity and impaired prohormone processing associated with mutations in the human prohormone convertase 1 gene. Nat Genet 1997; 16(3):303-306.

4 Krude H, Biebermann H, Luck W, Horn R, Brabant G, Gruters A: Severe early-onset obesity, adrenal insufficiency and red hair pigmentation caused by POMC mutations in humans. Nat Genet 1998;19(2):155-157.

$\checkmark 5$ Lee YS, Poh LK, Loke KY: A novel melanocortin 3 receptor gene (MC3R) mutation associated with severe obesity. J Clin Endocrinol Metab 2002; 87(3):1423-1426.

6 Tao YX, Segaloff DL: Functional characterization of melanocortin-3 receptor variants identify a loss-of-function mutation involving an amino acid critical for $\mathrm{G}$ protein-coupled receptor activation. J Clin Endocrinol Metab 2004;89(8):3936-3942.

7 Yeo GS, Farooqi IS, Aminian S, Halsall DJ, Stanhope RG, O'Rahilly S: A frameshift mutation in MC4R associated with dominantly inherited human obesity. Nat Genet 1998;20(2):111-112.

$>8$ Vaisse C, Clement K, Guy-Grand B, Froguel P: A frameshift mutation in human MC4R is associated with a dominant form of obesity. Nat Genet 1998; 20(2):113-114.

9 Holder JL, Jr., Butte NF, Zinn AR: Profound obesity associated with a balanced translocation that disrupts the SIM1 gene. Hum Mol Genet 2000; 9(1):101-108.

10 Larsen LH, Echwald SM, Sorensen TI, Andersen T, Wulff BS, Pedersen O: Prevalence of mutations and functional analyses of melanocortin 4 receptor variants identified among 750 men with juvenile-onset obesity. J Clin Endocrinol Metab 2005; 90(1):219-224.

11 Gantz I, Miwa H, Konda Y, Shimoto Y, Tashiro T, Watson SJ, DelValle J, Yamada T: Molecular cloning, expression, and gene localization of a fourth melanocortin receptor. J Biol Chem 1993; 268(20):15174-15179.
12 Mountjoy KG, Mortrud MT, Low MJ, Simerly $\mathrm{RB}$, Cone RD: Localization of the melanocortin-4 receptor (MC4-R) in neuroendocrine and autonomic control circuits in the brain. Mol Endocrinol 1994;8(10):1298-1308.

13 Ollmann MM, Wilson BD, Yang YK, Kerns JA, Chen Y, Gantz I, Barsh GS: Antagonism of central melanocortin receptors in vitro and in vivo by agouti-related protein. Science 1997;278(5335): 135-138.

14 Huszar D, Lynch CA, Fairchild-Huntress V, Dunmore JH, Fang Q, Berkemeier LR, Gu W, Kesterson RA, Boston BA, Cone RD, Smith FJ, Campfield LA, Burn P, Lee F: Targeted disruption of the melanocortin-4 receptor results in obesity in mice. Cell 1997;88(1):131-141.

15 Miraglia Del Giudice E, Cirillo G, Nigro V, Santoro N, D'Urso L, Raimondo P, Cozzolino D, Scafato D, Perrone L: Low frequency of melanocortin-4 receptor (MC4R) mutations in a Mediterranean population with early-onset obesity. Int J Obes Relat Metab Disord 2002;26(5):647-651.

16 Buono P, Pasanisi F, Nardelli C, Ieno L, Capone S, Liguori R, Finelli C, Oriani G, Contaldo F, Sacchetti L: Six novel mutations in the proopiomelanocortin and melanocortin receptor 4 genes in severely obese adults living in southern Italy. Clin Chem 2005;51(8):1358-1364.

17 Branson R, Potoczna N, Kral JG, Lentes KU, Hoehe MR, Horber FF: Binge eating as a major phenotype of melanocortin 4 receptor gene mutations. N Engl J Med 2003;348(12):1096-1103.

18 Dubern B, Clement K, Pelloux V, Froguel P, Girardet JP, Guy-Grand B, Tounian P: Mutational analysis of melanocortin-4 receptor, agouti-related protein, and alpha-melanocyte-stimulating hormone genes in severely obese children. J Pediatr 2001; 139(2):204-209.

19 Farooqi IS, Keogh JM, Yeo GS, Lank EJ, Cheetham T, O'Rahilly S: Clinical spectrum of obesity and mutations in the melanocortin 4 receptor gene. N Engl J Med 2003;348(12):1085-1095.

20 Hainerova I, Larsen LH, Holst B, Finkova M, Hainer V, Lebl J, Hansen T, Pedersen O: Melanocortin 4 receptor mutations in obese Czech children: studies of prevalence, phenotype development, weight reduction response, and functional analysis. J Clin Endocrinol Metab 2007;92(9):3689-3696.

21 Hinney A, Bettecken T, Tarnow P, Brumm H, Reichwald K, Lichtner P, Scherag A, Nguyen TT, Schlumberger P, Rief W, Vollmert C, Illig T, Wichmann HE, Schafer H, Platzer M, Biebermann H, Meitinger T, Hebebrand J: Prevalence, spectrum, and functional characterization of melanocortin-4 receptor gene mutations in a representative population-based sample and obese adults from Germany. J Clin Endocrinol Metab 2006;91(5):1761-1769.
22 Jacobson P, Ukkola O, Rankinen T, Snyder EE, Leon AS, Rao DC, Skinner JS, Wilmore JH, Lonn L, Cowan GS Jr, Sjostrom L, Bouchard C: Melanocortin 4 receptor sequence variations are seldom a cause of human obesity: the Swedish Obese Subjects, the HERITAGE Family Study, and a Memphis cohort. J Clin Endocrinol Metab 2002;87(10): $4442-4446$.

23 Santos JL, Amador P, Valladares M, Albala C, Martinez JA, Marti A: Obesity and eating behaviour in a three-generation Chilean family with carriers of the Thrl50Ile mutation in the melanocortin-4 receptor gene. J Physiol Biochem 2008;64(3): 205-210.

24 Wangensteen T, Kolsgaard ML, Mattingsdal M, Joner G, Tonstad S, Undlien D, Retterstol L: Mutations in the melanocortin 4 receptor (MC4R) gene in obese patients in Norway. Exp Clin Endocrinol Diabetes 2009;117(6):266-273.

25 Farooqi IS, Yeo GS, Keogh JM, Aminian S, Jebb SA, Butler G, Cheetham T, O'Rahilly S: Dominant and recessive inheritance of morbid obesity associated with melanocortin 4 receptor deficiency. J Clin Invest 2000;106(2):271-279.

26 Kobayashi H, Ogawa Y, Shintani M, Ebihara K, Shimodahira M, Iwakura T, Hino M, Ishihara T, Ikekubo K, Kurahachi H, Nakao K: A Novel homozygous missense mutation of melanocortin-4 receptor (MC4R) in a Japanese woman with severe obesity. Diabetes 2002;51(1):243-246.

27 Lubrano-Berthelier C, Le Stunff C, Bougneres P, Vaisse C: A homozygous null mutation delineates the role of the melanocortin-4 receptor in humans. J Clin Endocrinol Metab 2004;89(5):2028-2032.

28 Dubern B, Bisbis S, Talbaoui H, Le Beyec J, Tounian P, Lacorte JM, Clement K: Homozygous null mutation of the melanocortin-4 receptor and severe early-onset obesity. J Pediatr 2007;150(6):613$617,617 \mathrm{e} 1$

29 Lubrano-Berthelier C, Durand E, Dubern B Shapiro A, Dazin P, Weill J, Ferron C, Froguel P, Vaisse C: Intracellular retention is a common characteristic of childhood obesity-associated MC4R mutations. Hum Mol Genet 2003;12(2):145-153.

30 Yeo GS, Lank EJ, Farooqi IS, Keogh J, Challis BG, O'Rahilly S: Mutations in the human melanocortin-4 receptor gene associated with severe familial obesity disrupts receptor function through multiple molecular mechanisms. Hum Mol Genet 2003;12(5):561-574.

31 Lubrano-Berthelier C, Dubern B, Lacorte JM, Picard F, Shapiro A, Zhang S, Bertrais S, Hercberg S, Basdevant A, Clement K, Vaisse C: Melanocortin 4 receptor mutations in a large cohort of severely obese adults: prevalence, functional classification, genotype-phenotype relationship, and lack of association with binge eating. J Clin Endocrinol Metab 2006;91(5):1811-1818. 
-32 Tao YX: Molecular mechanisms of the neural melanocortin receptor dysfunction in severe early onset obesity. Mol Cell Endocrinol 2005;239(1-2): $1-14$

-33 Govaerts C, Srinivasan S, Shapiro A, Zhang S, Picard F, Clement K, Lubrano-Berthelier C, Vaisse $\mathrm{C}$ : Obesity-associated mutations in the melanocortin 4 receptor provide novel insights into its function. Peptides 2005;26(10):1909-1919.

34 Loos RJ, Lindgren CM, Li S, Wheeler E, et al: Common variants near MC4R are associated with fat mass, weight and risk of obesity. Nat Genet 2008; 40(6):768-775.

35 Willer CJ, Speliotes EK, Loos RJ, et al.: Six new loci associated with body mass index highlight a neuronal influence on body weight regulation. Nat Genet 2009;41(1):25-34

-36 Thorleifsson G, Walters GB, Gudbjartsson DF, Steinthorsdottir V, Sulem P, Helgadottir A, Styrkarsdottir U, Gretarsdottir S, Thorlacius S, Jonsdottir I, Jonsdottir T, Olafsdottir EJ, Olafsdottir GH, Jonsson T, Jonsson F, Borch-Johnsen K, Hansen T, Andersen G, Jorgensen T, Lauritzen T, Aben KK, Verbeek AL, Roeleveld N, Kampman E, Yanek LR, Becker LC, Tryggvadottir L, Rafnar T, Becker DM, Gulcher J, Kiemeney LA, Pedersen O, Kong A, Thorsteinsdottir U, Stefansson $\mathrm{K}$ : Genome-wide association yields new sequence variants at seven loci that associate with measures of obesity. Nat Genet 2009;41(1):18-24.

37 Meyre D, Delplanque J, Chevre JC, Lecoeur C, Lobbens S, Gallina S, Durand E, Vatin V, Degraeve F, Proenca C, Gaget S, Korner A, Kovacs P, Kiess W, Tichet J, Marre M, Hartikainen AL, Horber F, Potoczna N, Hercberg S, Levy-Marchal C, Pattou F, Heude B, Tauber M, McCarthy MI, Blakemore AI, Montpetit A, Polychronakos C, Weill J, Coin LJ, Asher J, Elliott P, Jarvelin MR, Visvikis-Siest S, Balkau B, Sladek R, Balding D, Walley A, Dina C, Froguel P: Genome-wide association study for early-onset and morbid adult obesity identifies three new risk loci in European populations. Nat Genet 2009;41(2):157-159.
38 Heard-Costa NL, Zillikens MC, Monda KL, et al: NRXN3 is a novel locus for waist circumference: a genome-wide association study from the CHARGE Consortium. PLoS Genet 2009;5(6): e1000539.

39 Beckers S, Mertens I, Peeters A, Van Gaal L, Van Hul W: Screening for melanocortin-4 receptor mutations in a cohort of Belgian morbidly obese adults and children. Int J Obes (Lond) 2006;30(2): 221-225.

40 Roelants M, Hauspie R, Hoppenbrouwers K: References for growth and pubertal development from birth to 21 years in Flanders, Belgium. Ann Hum Biol 2009;36(6):680-694.

$41 \mathrm{Gu}$ W, Tu Z, Kleyn PW, Kissebah A, Duprat L, Lee J, Chin W, Maruti S, Deng N, Fisher SL, Franco LS, Burn P, Yagaloff KA, Nathan J, Heymsfield S, Albu J, Pi-Sunyer FX, Allison DB: Identification and functional analysis of novel human melanocortin-4 receptor variants. Diabetes 1999;48(3):635-639.

42 Geller F, Reichwald K, Dempfle A, Illig T, Vollmert C, Herpertz S, Siffert W, Platzer M, Hess C, Gudermann T, Biebermann H, Wichmann HE, Schafer H, Hinney A, Hebebrand J: Melanocortin-4 receptor gene variant I103 is negatively associated with obesity. Am J Hum Genet 2004; 74(3):572-581.

43 Stutzmann F, Vatin V, Cauchi S, Morandi A, Jouret B, Landt O, Tounian P, Levy-Marchal C, Buzzetti R, Pinelli L, Balkau B, Horber F, Bougneres P, Froguel P, Meyre D: Non-synonymous polymorphisms in melanocortin-4 receptor protect against obesity: the two facets of a Janus obesity gene. Hum Mol Genet 2007;16(15):1837-1844.

44 Biebermann H, Krude H, Elsner A, Chubanov V, Gudermann T, Gruters A: Autosomal-dominant mode of inheritance of a melanocortin-4 receptor mutation in a patient with severe early-onset obesity is due to a dominant-negative effect caused by receptor dimerization. Diabetes 2003;52(12):29842988.
45 Stutzmann F, Tan K, Vatin V, Dina C, Jouret B, Tichet J, Balkau B, Potoczna N, Horber F, O'Rahilly S, Farooqi IS, Froguel P, Meyre D: Prevalence of melanocortin-4 receptor deficiency in Europeans and their age-dependent penetrance in multigenerational pedigrees. Diabetes 2008;57(9):2511-2518.

46 Reinehr T, Hinney A, de Sousa G, Austrup F, Hebebrand J, Andler W: Definable somatic disorders in overweight children and adolescents. J Pediatr 2007;150(6):618-622, 622 e1-5.

47 Tao YX, Segaloff DL: Functional analyses of melanocortin-4 receptor mutations identified from patients with binge eating disorder and nonobese or obese subjects. J Clin Endocrinol Metab 2005; 90(10):5632-5638.

48 Ho G, MacKenzie RG: Functional characterization of mutations in melanocortin-4 receptor associated with human obesity. J Biol Chem 1999; 274(50):35816-35822.

49 VanLeeuwen D, Steffey ME, Donahue C, Ho G, MacKenzie RG: Cell surface expression of the melanocortin-4 receptor is dependent on a C-terminal di-isoleucine sequence at codons 316/317. J Biol Chem 2003;278(18):15935-15940.

50 Fang QC, Jia WP, Cai SB, Shao XY, Zhang R, Wang CR, Bao YQ, Xiang KS: Intracellular retention of human melanocortin-4 receptor: a molecular mechanism underlying early-onset obesity in F261S pedigree of Chinese. Biomed Environ Sci 2008;21(4):280-285.

51 Hinney A, Hohmann S, Geller F, Vogel C, Hess C, Wermter AK, Brokamp B, Goldschmidt H, Siegfried W, Remschmidt H, Schafer H, Gudermann T, Hebebrand J: Melanocortin-4 receptor gene: casecontrol study and transmission disequilibrium test confirm that functionally relevant mutations are compatible with a major gene effect for extreme obesity. J Clin Endocrinol Metab 2003;88(9):42584267.

52 Tao YX, Segaloff DL: Functional characterization of melanocortin-4 receptor mutations associated with childhood obesity. Endocrinology 2003; 144(10):4544-4551. 